\title{
Is There a Surplus of Non-Specialist Physicians in Portugal or Just Poor Human Resources Planning?
}

\section{Portugal Sofre de Um Excedente de Médicos Não Especializados ou Apenas de Um Défice de Planeamento de Recursos Humanos?}

\author{
Francisco RIBEIRO-MOURÃO ${ }^{1,2,3}$, António ARAÚJO ${ }^{4,5,6}$, Carlos CORTES ${ }^{7,8}$, Tiago VILLANUEVA ${ }^{9,10}$, \\ João Carlos RIBEIRO $₫ 9,11,12$ \\ Acta Med Port 2018 Nov;31(11):609-611 - https://doi.org/10.20344/amp.11273
}

Keywords: Education, Medical, Graduate; Internship and Residency; Physicians/supply \& distribution; Portugal

Palavras-chave: Educação de Pós-Graduação em Medicina; Internato e Residência; Médicos/provisão \& distribuição; Portugal

During the last three years an apparently new phenomenon occurred in Portugal - the emergence of non-specialist physicians. Only apparently new, because most of our older population still remembers what it was like 30 years ago. Throughout the last few decades, the improvement in the population's healthcare status reflected the appearance of new generations of more differentiated physicians. But what is currently happening?

Right now, it is obvious that many physicians cannot access post-graduate training. In 2015 we witnessed the beginning of this new generation of non-specialist physicians when there were 1578 training vacancies for 1796 candidates (meaning that $92 \%$ of them had a specialist training post available). ${ }^{1}$ In 2018 only $71 \%$ of the candidates had a training post available. Even though many candidates give up during the competitive recruitment scheme, a substantial part of them will accrue for the following year, triggering a snow-ball effect. ${ }^{1}$

This means we are being challenged with increasing numbers of non-specialist physicians every year. This scenario raises some concerns: how and why have we reached this situation, what is the country's and other stakeholders' goals for these highly differentiated professionals and what will be the future of these physicians.

1. How have we reached this situation? This has apparently been due to an excessive number of admissions to medical school associated with a long-term lack of a human resources planning strategy for healthcare. Demagogical political decisions that go way beyond the political cycles and medical school funding interests also helped worsen this scenario.

2. Can we increase post-graduate training (PGT) capacity? Despite being systematically conveyed that the training capacity in the public and private sectors as well as in social institutions is above its limit, there was a modest increase in the vacancies for PGT until 2017. However, in 2018 these figures decreased compared to $2017 .{ }^{1}$ Has the Portuguese Medical Association (Ordem dos Médicos) been stricter in applying the criteria for training capacity? Or are the departments losing training capacity due to the lack of investment on material and human resources that lead to worse working conditions compared to previous years? A brief look at the weekly news about medical training across different institutions should raise our concerns that we are not, in many cases, training the highly-qualified professionals that the country needs and desires.

One should also bear in mind that the National Health Service organizations are still, by far, the leading providers of medical training in Portugal. Any measures that decrease or weaken its activity have an important impact on its training capacity and subsequently on the number of post-graduate training posts.

Finally, there is a dilemma between offering vacancies for all the candidates and still respecting the training capacity and providing high-quality post-graduate medical training. The answer is easy for politicians but is extremely difficult for physicians and patients who will not certainly want poorly trained professionals to provide specialized medical services in the future.

3. What is the future of non-specialist physicians? One

\footnotetext{
1. Serviço de Pediatria. Unidade Local de Saúde do Alto Minho. Viana do Castelo. Portugal.

2. Conselho Nacional do Médico Interno. Ordem dos Médicos. Portugal.

3. Postgraduate Medical Training Committee. European Junior Doctors Association. Brussels. Belgium.

4. Conselho Regional do Norte. Ordem dos Médicos. Porto. Portugal.

5. Serviço de Oncologia Médica. Centro Hospitalar do Porto. Porto. Portugal.

6. Instituto de Ciências Biomédicas Abel Salazar. Porto. Portugal.

7. Conselho Regional do Centro. Ordem dos Médicos. Coimbra. Portugal.

8. Conselho Nacional para a Pós- Graduação. Ordem dos Médicos. Lisboa. Portugal.

9. Acta Médica Portuguesa. Lisboa. Portugal.

10. Unidade de Saúde Familiar Reynaldo dos Santos. Póvoa de Santa Iria. Portugal.

11. Department of Otorhinolaryngology. Coimbra University Hospitals. Coimbra. Portugal.

12. Faculty of Medicine. University of Coimbra. Coimbra. Portugal.

$\bowtie$ Autor correspondente: João Carlos Ribeiro. jcarlosribeiro@uc.pt

Recebido: 10 de setembro de 2018 - Aceite: 14 de setembro de 2018 | Copyright @ Ordem dos Médicos 2018
} 
issue frequently raised is that not every medical graduate needs to pursue a post-graduate training program or to work in a clinical setting. Despite being a valid assumption, the figures reveal a different reality. The majority of the candidates that do not secure a training post in one year tend to re-apply in the following year, in order to pursue their clinical career. But many physicians are going abroad or moving exclusively to the private sector. This includes not only non-specialists, but also the best and brightest specialists. ${ }^{2}$ Consequently, the most wanted and needed training posts are progressively disappearing. ${ }^{1}$ Moreover, it should be a matter of public discussion if the tax-payers should be funding these expensive degrees that will not be used for the country's benefit or that will not be used for the benefit of daily clinical practice when their training was highly directed towards clinical practice and paid as such. If there is a need for more professionals in the health sciences fields or for biomedical research, would these professionals not benefit from a different kind of training, one that is directed towards its specificities, instead of having a training process that is highly focused on the clinical setting? Moreover, there is also an ethical and moral cost that is not being properly considered - thousands of patients are being unnecessarily exposed to ensure the undergraduate training of professionals that will not be working in this setting later on in their career.

4. Who benefits from this situation? The surplus of non-specialized physicians is likely to be of great interest to some entities that includes not only private practice and research stakeholders, but also the general population that may be misled to think that the more physicians, the better will our healthcare system be.

There are the ones who, by political views, strongly believe that numerus clausus should not exist, that the State should be responsible for all the funding and that the training capacity should be dictated by the number of candidates, regardless of the quality of training or of the country's needs. Therefore, the increasing exodus of Portuguese physicians seems unsurprising and comparable to the migration of other professionals. The best practical example of this view and with known consequences worldwide is Cuba. ${ }^{3}$ Non-specialist physicians in an increasingly competitive market are appealing to entities looking for low cost medical labour (and the liability linked to it) without considering the best result for the patient and the best benefit for the health system.

The existence of non-specialist physicians is not new in Portugal. However, we have evolved, as a country, in a different direction with recent worldwide recognized excellent results. ${ }^{4}$

However, the need for generalist physicians is also widely advocated as sub-specialization could lead to the loss of the holistic approach for the patient. However, even if this vision may be assumed, we have developed in an ambitious general practice / family medicine specialist training program in Portugal. ${ }^{5}$

General Practice / Family Medicine constitute by itself an area of specialized expertise. Several other countries have also recognized the need to extend the duration of the post-graduate training in General Practice / Family Medicine, valuing their educational needs and their impact on the system as a whole. ${ }^{6}$

5. Where are we heading? We are heading against international medical education standards that advocate the number of professionals in training should be proportional to the training opportunities available and to the training capacity. $^{7}$

A considerable number of non-specialists is now being deployed to work as gatekeepers of our healthcare system: either by staffing the frontline in many emergency departments or seeing patients in primary care without an assigned family doctor. These doctors, therefore, are carrying out tasks that fall under the remit of a specific medical specialty. Many will also choose to leave the country in order to find other opportunities. The investment that the country made in these professionals will be delivered, totally free of cost, to some nations that chose not to invest in the undergraduate training of medical professionals as they would certainly be provided by someone else for free. ${ }^{8}$

We cannot peremptorily say there is (or not) a surplus of doctors in Portugal. It is quite easy to overestimate, underestimate and misclassify the supply of physicians. Many variables are impairing this analysis, including the immigration of international medical graduates and the emigration of Portuguese medical graduates. Several other countries have shown similar problems, without clear solutions and different constraints. ${ }^{9}$ Nevertheless, we can easily conclude that we have been educating high quality professionals and many of them are not working in our national public health system, thus not yielding the same benefit for the population that would be desired by everyone. In the meantime, we will keep systematically advocating for a better distribution of healthcare professionals, better patient accessibility to health services and better health outcomes.

\section{CONFLICTS OF INTEREST}

The authors report no conflict of interest.

3. de Albornoz SC. On a mission: how Cuba uses its doctors abroad. BMJ. 2006;333:464.

4. de Almeida Simoes J, Augusto GF, Fronteira I, Hernandez-Quevedo C. Portugal: health system review. Health Syst Transit. 2017;19:1-184.

5. Gaspar D. General practice and family medicine vocational training: the specialty internship doctor's profile, in Portugal. Acta Med Port. 2010;23:39-50. 
6. Independent Comission for The Royal College of General Practioners and the Health Foundation. Guiding patients through complexity: modern medical generalism. London; 2011.

7. World Federation for Medical Education. Postgraduate medical education - WFME global standards for quality improvement. Copenhagen:WFME; 2015.

8. Tomblin Murphy G, Birch S, MacKenzie A, Bradish S, Elliott Rose A.
A synthesis of recent analyses of human resources for health requirements and labour market dynamics in high-income OECD countries. Hum Resour Health. 2016;14;59.

9. Joe M. The Association of Patient Care Load and Health Inequities: a comparison of physicians in the United States, Germany, and Japan. Knoxville: University of Tenneessee; 2016. 